Reprod. Nutr. Dévelop., 1985, 25 (3), 567-581.

\title{
Incidence of (n-3) essential fatty acid deficiency on trout reproductive processes.
}

\author{
C. LERAY, G. NONNOTTE, P. ROUBAUD (*), C. LÉGER $\left(^{* *}\right)$ \\ C.N.R.S., B.P. 20 CR, 67037 Strasbourg Cedex, France. \\ (*) Station de Physiologie animale, Groupe Embryologie \\ des Poissons, I.N.R.A., 78350 Jouy-en-Josas, France. \\ (**) Station de Recherches de Nutrition, I.N.R.A., \\ 78350 Jouy-en-Josas, France.
}

Summary. A feeding experiment was conducted on rainbow trout broodstock for one year to investigate the influence of the quality of dietary lipids on egg and fry fatty acid composition, embryonic development and hatching efficiency. The broodstock were fed either a commercial control diet or a (n-3) fatty acid-deficient diet ; their liver, eggs and fry were analysed to determine the fatty acid composition of their neutral and polar lipids. The fatty acid pattern in liver, eggs and fry was markedly different due to the qualitative difference of the dietary lipids. The most striking difference was the low amount of 22:6 $(n-3)$ and the high levels of 20:4 (n-6) and 22:5 (n-6) in phospholipids of fish receiving the $(n-3)$-deficient diet containing a high level of 18:2 (n-6). While fertilization efficiency was equivalent in the first two days of development, whatever the diet, two peaks of mortality were observed, one at day 8 and the other at day 22 after fertilization, during the time the eggs produced by the deficient fish were incubated. A shorter period of vitellus resorption (50 vs 65 day) was observed in (n-3)-deficient alevins as compared to controls.

Morphological study of the development of the (n-3)-deficient embryos showed some cleavage disorders at the 16 to 32-cell stage, a blocking effect before gastrulation, and later various alterations in organogenesis. It was concluded that (n-3) fatty acids, and especially 22:6 (n-3), play a crucial and specific role in trout embryo development. These fatty acids could be involved in cellular recognition processes through their oxygenated derivatives. The need for long-term nutritional deficiency to induce the reported biochemical and physiological alterations is discussed.

\section{Introduction.}

Extensive dietary studies have shown the essentiality and requirement of (n-3) fatty acids in rainbow trout. Castell et al. (1972a,b,c) described several deficiency symptoms and physiological changes leading to the concept that the linolenic acid familty is essential to trout. Early biochemical studies combined with growth and mortality observations (Lee et al., 1967) revealed that the fatty acid composition of body phospholipids reflects the dietary fatty acid pattern, as shown for neutral lipids (Léger and Frémont, 1980). Further works have largely confirmed the quantitative requirement and essentiality of the linolenic series in 
trout (Yu and Sinnhuber, 1972, 1975, 1976 ; Watanabe et al., 1974a,b) ; several studies have pointed out that the highly unsaturated components of this series (20:5 up to 22:6) may have essential fatty acid (EFA) activity in trout (Watanabe and Takeuchi, 1976 ; Takeuchi and Watanabe, 1976, 1977 ; Yu and Sinnhuber, 1972). In addition to growth studies, data on the physiological symptoms of EFA deficiency in trout include several processes such as necrosis of caudal fins, dermal depigmentation, increased water content, shock syndrome, increased mitochondrial swelling and heart myopathy (Sinnhuber et al., 1972). In contrast, the demonstration of the role of lipids in the reproductive physiology of fish has received little attention. While it was shown that docosahexaenoic acid (22:6n-3) tends to be selectively retained in trout fry (Hayes et al., 1973 ; Atchison, 1975), linolenic acid, as a sole lipid source for 34 months, was shown to sustain normal growth and reproduction in this species (Yu et al., 1979). In carp, Shimma et al. (1977) reported a relationship between hatchability and the proportion of 22:6 $(n-3)$ in egg lipids. Watanabe (1982) reported that a casein diet devoid of unsaturated fatty acids greatly affected the spawning of rainbow trout and red sea bream, while the addition of ethyl linoleate improved egg condition to a level comparable with that in the control trout. Furthermore, in a recent paper Watanabe et al. (1984c) stated that the hatchability of trout eggs is not solely related to egg 22:6 (n-3) content and suggested that linoleic acid may have some EFA value (possibly through its bioconversion into arachidonic acid) in rainbow trout reproduction. In contrast, Watanabe et al. (1984a,b) demonstrated that the reproduction of red sea bream is greatly affected by the (n-3) fatty acid content of the broodstock diet.

The present study was conducted on trout one year before spawning to investigate the respective effects of dietary fatty acids of the (n-3) and (n-6) series on egg and fry fatty acid composition and to relate the observed changes to embryonic development which largely depends on egg quality.

\section{Material and methods.}

Eggs produced by rainbow trout broodstock maintained in the laboratory experimental station were hatched. The fish were fed a commercial trout diet (diet C, Kraft Universal Corporation) for 2 years while growing to about $500 \mathrm{~g}$ of body weight. Two groups of fifteen adult females were stocked in outdoor circular polyethylene tanks $1.2 \mathrm{~m}$ in diameter and provided with well-aerated fresh running water (undergound water temperature: $12-13^{\circ} \mathrm{C}$ ). They were fed either the control diet (C) or a semi-purified (n-3)-deficient diet (D) prepared according to Castell et al. (1972c) and containing $8 \%$ of grapeseed oil. Diets C and D were given once daily (1\% of body weight) for one year until spawning time in January. Their fatty acid composition is shown in table 1. In January, four females (average weight: $750 \mathrm{~g}$ ) were selected from lots $C$ and $D$ for first spawning, egg and tissue sampling and egg fertilization. The males used for sperm collection and egg fertilization were selected from trout maintained on diet C. 
The ripe eggs were lyophilized and their total lipids were extracted according to Folch et al. (1957). Using the same procedure, the total lipids were also extracted from the lipovitellin, or yolk globule (prepared as described by Léger et al., 1981b), of fry collected 3 days after complete yolk absorption and from the liver of the selected broodstocks. The total lipids were separated into " neutral " and "polar " fractions by thin-layer chromatography (solvent mixture : diethyl ether/methanol/acetic acid; 90/2/1). Fatty acid butyl esters, prepared as described previously (Di Costanzo et al., 1983), were analysed with a Perkin-Elmer Sigma 1 gas chromatograph equipped with a glass wall-coated open-tubular column $(0.35 \mathrm{~mm}$ id $\times 50 \mathrm{~m})$. The stationary phase used was carbowax $20 \mathrm{M}$ (Flanzy et al., 1976). Peak areas were determined by the in-line Perkin-Elmer Sigma 10 chart integrator.

Approximately 1000 to 2000 eggs from each female were fertilized in a diluent solution at $\mathrm{pH} 9.5$ containing $95 \mathrm{mM} \mathrm{NaCl}, 20 \mathrm{mM}$ tris buffer and $50 \mathrm{mM}$ glycine $(10 \mathrm{ml}$ of solution for $100 \mu \mathrm{l}$ of sperm) ; they were incubated in the dark in separate rearing tanks at $11 \pm 0.5^{\circ} \mathrm{C}$ in air-saturated water. The survival of the eggs of each female was monitored every day from fertilization to hatching time, the mortality test being vitellus coagulation (the opalescent or "white egg " aspect used in trout culture). This test is simple to use but is obviously related to lethal events occurring previously during embryogenesis. At regular intervals after fertilization $(2,4,8,24,48,96$ and $192 \mathrm{~h})$, samples of 20 embryos each were collected from the lots produced by ( $n-3)$-deficient females and fixed in alcoholic

TABLE 1

Fatty acid composition (mole \%) of the diets.

\begin{tabular}{|c|c|c|}
\hline \multirow{2}{*}{ Fatty acids } & \multicolumn{2}{|c|}{ Diet } \\
\hline & C & D \\
\hline $14: 0$ & 10.0 & - \\
\hline 16:0 & 20.9 & 8.6 \\
\hline 18:0 & 3.1 & 3.8 \\
\hline$\Sigma$ Sat. & 34.0 & 12.4 \\
\hline $22: 1(n-11)$ & 3.5 & - \\
\hline 16:1 (n-7) & 3.9 & - \\
\hline $18: 1(n-7)$ & 1.7 & 0.6 \\
\hline$\Sigma(n-7)$ & 5.6 & 0.6 \\
\hline $18: 1(n-9)$ & 16.7 & 17.8 \\
\hline $20: 1(n-9)$ & 4.4 & - \\
\hline$\Sigma(n-9)$ & 21.1 & 17.8 \\
\hline $18: 2(n-6)$ & 23.1 & 67.2 \\
\hline $20: 4(n-6)$ & 0.5 & - \\
\hline$\Sigma(n-6)$ & 23.6 & 67.2 \\
\hline $18: 3(n-3)$ & 2.5 & - \\
\hline $18: 4(n-3)$ & 1.0 & - \\
\hline $20: 5(n-3)$ & 3.5 & - \\
\hline $22: 6(n-3)$ & 5.0 & - \\
\hline$\Sigma(n-3)$ & 12.0 & - \\
\hline
\end{tabular}

C : commercial diet containing $10.5 \%$ lipid.

D : (n-3)-deficient diet containing $8 \%$ grape seed oil as lipid source. 
Bouin fluid. These embryos were observed and photographed with an Olympus stereomicroscope zoom SZ-TR equipped with a optic fiber illuminating device (O.E.B. $150 \mathrm{w}$ ), the dissected egg lying in a small hole cut in a dark plate.

\section{Results and discussion.}

\section{Fatty acid distribution in liver lipids.}

The influence of dietary fatty acids on the fatty acid composition of the liver is shown in table 2. A higher proportion of (n-3) fatty acids was found in the neutral and polar lipids with the control diet than with the (n-3)-deficient diet. The level of 22:6 (n-3) fatty acids in polar lipids of trout fed diet $C$ was particularly high compared to that of trout fed diet $D$ ( 23.9 vs $5.0 \%$, respectively), and the level of (n-6) fatty acids (18:2 and 20:4 in polar and neutral lipids) was lower. In polar lipids of trout fed diet $C$, the percentages of highly polyunsaturated fatty acids (HPUFA) $\left(^{*}\right)$, compared to total polyunsaturated fatty acids, were 95 and $67 \%$ for the $(n-3)$ and $(n-6)$ series, respectively. They were 82 and $62 \%$ with the $(n-3)$-deficient diet and thus higher for the (n-3) than for the $(n-6)$ series. The lower efficiency of the bioconversion system with the $(n-6)$ series could be due to the high dietary content of 18:2 (n-6), leading to an overloading of the enzyme system or, more likely, to a higher affinity of $\Delta 6$ desaturase (the first desaturase involved in bioconversion) for the most unsaturated fatty acid (18:3 n-3 vs 18:2 $\mathrm{n}-6$ ), as described in mammals (Brenner, 1971).

Preferential incorporation and bioconversion of ingested (n-3) fatty acids have already been observed in trout (Yu and Sinnhuber, 1975, 1976 ; Lee et al., 1967 ; Watanabe, 1982 ; Léger et al., 1981a). Similar compositions of polar lipids

TABLE 2

Simplified fatty acid compositions (mole \%) of liver polar and neutral lipids in mature trout fed diet $C$ or $D$.

\begin{tabular}{|c|c|c|c|c|}
\hline \multirow{2}{*}{ Fatty acids } & \multicolumn{2}{|c|}{ Polar lipids } & \multicolumn{2}{|c|}{ Neutral lipids } \\
\hline & Diet Ca & Diet $D^{b}$ & Diet Ca & Diet $D^{b}$ \\
\hline$\Sigma$ Sat. & $32.2 \pm 0.9$ & $31.2 \pm 0.9$ & $28.5 \pm 2.5$ & $29.9 \pm 1.6$ \\
\hline$\Sigma(n-7)$ & $5.0 \pm 0.8$ & $3.1 \pm 0.1$ & $8.3 \pm 0.6$ & $4.7 \pm 0.9$ \\
\hline $\bar{\Sigma}(\mathrm{n}-9)$ & $16.5 \pm 1.4$ & $14.5 \pm 0.6$ & $30.6 \pm 1.7$ & $19.8 \pm 0.9$ \\
\hline$\Sigma(n-6)$ & $18.3 \pm 0.9$ & $47.4 \pm 0.8$ & $18.7 \pm 1.3$ & $43.2 \pm 1.2$ \\
\hline$\Sigma(n-3)$ & $28.0 \pm 1.1$ & $3.9 \pm 0.6$ & $13.9 \pm 2.9$ & $2.5 \pm 0.4$ \\
\hline $18: 2(n-6)$ & $4.9 \pm 0.3$ & $10.8 \pm 0.8$ & $7.3 \pm 1.2$ & $16.7 \pm 1.5$ \\
\hline $20: 4(n-6)$ & $11.1 \pm 0.5$ & $24.0 \pm 1.0$ & $4.8 \pm 0.8$ & $12.2 \pm 0.7$ \\
\hline $22: 5(n-6)$ & $1.1 \pm 0.1$ & $5.7 \pm 0.3$ & - & $1.4 \pm 0.2$ \\
\hline $20: 5(n-3)$ & $2.6 \pm 0.2$ & I & $1.5 \pm 0.6$ & $1.4 \pm 0.2$ \\
\hline $22: 6(n-3)$ & $23.9 \pm 1.0$ & $3.2 \pm 0.6$ & $9.3 \pm 1.5$ & $0.8 \pm 0.5$ \\
\hline$(n-3) /(n-6)$ & $1.5 \pm 0.1$ & $0.08 \pm 0.01$ & $0.8 \pm 0.2$ & $0.06 \pm 0.01$ \\
\hline
\end{tabular}

$a$ : means of 4 determinations \pm SEM ; $b$ : means of 3 determinations \pm SEM.

$\left.{ }^{*}\right)(n-6)$ HPUFA $=20: 4+22: 5$ and $(n-3)$ HPUFA $=20: 5+22: 6$. 
have been seen in the liver of rainbow trout fed a commercial diet (Watanabe et al., 1984a), but higher $(n-3) / n-6)$ ratios were observed when only $18-3(n-3)$ or (n-3) HPUFA was incorporated into the basal diets (Takeuchi and Watanabe, 1982 ; Castell et al., 1972a). It is noteworthy that the decrease of (n-3) fatty acids, and particularly of 20:5 (n-3) and 22:6 (n-3), in vitellogenin and lipoprotein phospholipids is more pronounced with a (n-3)-deficient diet given for three months than with the same diets given for six months, suggesting that adaptation to the deficient diet occurred during the last three months (Frémont et al., 1984).

The percentage of (n-6) fatty acids in liver neutral lipids was like that of polar lipids but the percentage of (n-6) HPUFA was lower. On the other hand, these lipids contained a lower percentage of (n-3) fatty acids, especially of 22:6 (n-3), reflecting the specific affinities of the various acyltransferases prevailing in glyceride and phospholipid metabolisms (Léger and Frémont, 1980).

The high level of $20: 4(n-6)$ and the unusual presence of 22:5 (n-6) in the phospholipids of trout receiving diet $D$ can be explained. In the absence of dietary (n-3) fatty acids, there is no competitive inhibition of (n-6) fatty acid bioconversion (Brenner, 1971), and the high dietary content of the (n-6) series precursor led to an increase in the (n-6) HPUFA level, particularly that of 22:5 ( $n-6)$ resulting from the bioconversion of $18: 2(n-6)$ by elongase and $\Delta 6, \Delta 5$ and $\Delta 4$-desaturases. Finally, the phospholipids were selectively enriched by the most unsaturated fatty acids regardless of fatty acid series, as reported in rats (Tinoco et al., 1978).

It is noteworthy that the low bioconversion of 20:4 (n-6) into $22: 5$ (n-6) with diet $D$, compared to that of 20:5 (n-3) into 22:6 (n-3) with diet $C$, indicated the particularly low affinity of $\Delta 4$-desaturase in trout liver for the (n-6) series vs a high affinity for the ( $n-3)$ series. This difference was not detected when very young fish were fed (Yu and Sinnhuber, 1975 ; Takeuchi and Watanabe, 1982), but not enough biochemical studies have been carried out on this important enzyme step to permit further discussion.

As previously observed (Yu and Sinnhuber, 1975, 1976), trout fed the (n-3) EFA-deficient diet contained $(n-6)$ fatty acids did not synthesize the unusual polyenoic acid 20:3 (n-9). Thus the index of 20:3 (n-9)/20:4 (n-6), used in mammals (Holman, 1970) for demonstrating (n-6) EFA deficiency, obviously cannot be applied to ( $n-3)$-deficient trout. Neither can the ratio of 20:3 (n-9)/22:6 (n-3) proposed by Castell et al. (1972a), as it fails to take into account the (n-6) series as well as the 20:5 (n-3) which, in the (n-3) series, is the counterpart of 20:3 $(n-9)$ and 20:4 (n-6) in the (n-9) and $(n-6)$ series, respectively. The trout equivalent of the mammal index for ( $n-3)$ deficiency would be :

$$
\varrho=\frac{20: 3(n-9)+20: 4(n-6)+22: 5(n-6)}{20: 5(n-3)+22: 5(n-3)+22: 6(n-3)}
$$

This index is lower than 0.5 for liver polar and neutral lipids in control fish and between 6 and 12 in (n-3)-deficient fish. Similar values can be computed from data given by Castell et al. (1972a), Watanabe et al. (1974a) and $Y u$ and Sinnhuber (1975) studying lipid nutrition in trout.

The extent of modification of (n-3) fatty acid contents induced by feeding seems to depend on the duration of the experiment : a (n-3)-deficient diet 
supplemented with $5 \%$ linoleate and given to trout during the last three months of oogenesis was unable to significantly modify the (n-3) fatty acid content of liver polar lipids compared to a pollock liver oil-supplemented diet (Watanabe et al., 1984c).

\section{Fatty acid distribution in egg and fry lipids.}

It can be seen in table 3 that neither the whole lipid content of the eggs nor their neutral lipid portion were affected by dietary lipids. Various amounts of polar and non-polar lipids have been reported (Léger et al., 1981b ; Watanabe et al., 1978 ; Wiegand and Idler, 1982) for trout ovary and eggs, but differences in nutritional state, age, maturation stage and other uncontrolled criteria make comparison difficult.

TABLE 3

Egg lipid composition of trout fed diet $C$ or $D$.

\begin{tabular}{ccc}
\hline Diet & Total lipids $^{\text {a }}$ & \% Neutral lipids \\
\hline C & $435.5 \pm 44.7$ & $26.3 \pm 1.7$ \\
D & $396.5 \pm 24.7$ & $23.8 \pm 3.0$ \\
\hline
\end{tabular}

a : in $\mathrm{mg} / \mathrm{g}$ dry egg.

The fatty acid distribution of polar and neutral lipids in unfertilized eggs just after spawning is shown in table 4. As in liver, the fatty acid pattern of egg polar lipids is greatly affected by dietary lipids. In control fish only a few differences were detected between liver and egg fatty acid compositions. However, HPUFA levels were higher in the liver than in the eggs.

The (n-3) fatty acid-deficient diet had a strongly depressive effect on the (n-3) fatty acid content of eggs which was of the same order as in the liver. In contrast, half of the neutral and polar lipid fatty acids belonged to the (n-6) series.

TABLE 4

Simplified fatty acid compositions (mole \%) of egg polar and neutral lipids in mature trout fed diet $C$ or $D$.

\begin{tabular}{|c|c|c|c|c|}
\hline \multirow{2}{*}{ Fatty acids } & \multicolumn{2}{|c|}{ Polar lipids } & \multicolumn{2}{|c|}{ Neutral lipids } \\
\hline & Diet Ca & Diet $\mathrm{D}^{\mathrm{b}}$ & Diet $\mathrm{Ca}^{\mathrm{a}}$ & Diet $\mathrm{D}^{\mathrm{b}}$ \\
\hline$\Sigma$ Sat. & $35.1 \pm 0.7$ & $31.4 \pm 0.6$ & $24.7 \pm 0.3$ & $15.7 \pm 0.7$ \\
\hline$\Sigma(n-7)$ & $7.6 \pm 1.6$ & $2.7 \pm 0.1$ & $14.9 \pm 1.2$ & $5.0 \pm 0.8$ \\
\hline$\Sigma(n-9)$ & $17.2 \pm 1.2$ & $14.9 \pm 0.1$ & $41.8 \pm 0.7$ & $25.8 \pm 0.5$ \\
\hline$\Sigma(n-6)$ & $16.3 \pm 0.7$ & $48.9 \pm 0.9$ & $10.7 \pm 0.8$ & $52.6 \pm 2.0$ \\
\hline$\Sigma(n-3)$ & $23.8 \pm 1.9$ & $2.7 \pm 0.4$ & $8.0 \pm 0.9$ & $1.0 \pm 0.1$ \\
\hline $18: 2(n-6)$ & $3.2 \pm 0.2$ & $10.7 \pm 0.5$ & $5.2 \pm 0.3$ & $25.8 \pm 1.2$ \\
\hline $20: 4(n-6)$ & $8.2 \pm 0.5$ & $20.3 \pm 1.3$ & $2.6 \pm 0.3$ & $9.0 \pm 0.8$ \\
\hline $22: 5(n-6)$ & $1.5 \pm 0.3$ & $7.4 \pm 1.2$ & $0.6 \pm 0.2$ & $2.5+0.3$ \\
\hline $20: 5(n-3)$ & $2.0 \pm 0.3$ & - & $0.7 \pm 0.2$ & \pm \\
\hline $22: 6(n-3)$ & $20.7 \pm 1.2$ & $2.5 \pm 0.3$ & $7.0 \pm 0.7$ & $1.0 \pm 0.1$ \\
\hline$(n-3) /(n-6)$ & $1.5 \pm 0.2$ & $0.055 \pm 0.008$ & $0.75 \pm 0.04$ & $0.020 \pm 0.004$ \\
\hline
\end{tabular}

$a$ : means of 3 determinations \pm SEM ; $b$ : means of 4 determinations \pm SEM. 
(n-6) fatty acid distribution was similar to that in the liver, the 20:4 (n-6) and the 18:2 (n-6) fatty acid contents representing $40 \%$ of the $(n-6)$ series in polar and neutral lipids, respectively. However, the levels of $18: 2(n-6)$ were higher in the neutral lipids of eggs than in those of liver (25.8 vs $16.7 \%$ ). In control and (n-3) fatty acid-deficient fish, neutral lipids were characterized by a lower amount of saturated and (n-3) fatty acids and a higher amount of $(n-9)$ and $(n-7)$ fatty acids than polar lipids. Similar results were reported by Watanabe et al. (1978) for trout egg lipids.

The neutral lipid (oil globule) composition of trout eggs was only slightly affected by diets given three months before ovulation time (Léger et al., 1981b). The present study shows a more pronounced influence of dietary lipids on egg neutral lipids. This discrepancy can be attributed to the duration of the experimental period, as already mentioned for liver fatty acid composition.

The fatty acid composition of the polar lipids of egg lipovitellin was very similar to that of egg polar lipids in trout fed the $(n-3)$-deficient or the nondeficient diet (table 5). Thus, egg membrane fatty acid composition was closely related to that of lipovitellin phospholipids.

TABLE 5

Simplified fatty acid compositions (mole \%) of the polar lipids of egg lipovitellin in mature trout fed diet $C$ or $D$.

\begin{tabular}{lrr}
\hline & \multicolumn{2}{c}{ Polar lipids } \\
\cline { 2 - 3 } \multicolumn{1}{c}{ Fatty acids } & \multicolumn{1}{c}{ Diet $C^{a}$} & \multicolumn{1}{c}{ Diet $D^{b}$} \\
\hline$\sum$ Sat. & $33.7 \pm 1.0$ & $34.9 \pm 1.9$ \\
$\sum(n-7)$ & $8.0 \pm 1.8$ & $3.2 \pm 0.1$ \\
$\sum(n-9)$ & $16.4 \pm 0.8$ & $14.5 \pm 0.5$ \\
$\sum(n-6)$ & $17.6 \pm 0.7$ & $44.6 \pm 1.8$ \\
$\sum(n-3)$ & $24.3 \pm 1.9$ & $2.9 \pm 0.6$ \\
$18: 2(n-6)$ & $3.3 \pm 0.2$ & $7.5 \pm 2.2$ \\
$20: 4(n-6)$ & $9.3 \pm 0.7$ & $19.8 \pm 0.9$ \\
$22: 5(n-6)$ & $1.6 \pm 0.2$ & $6.4 \pm 0.6$ \\
$20: 5(n-3)$ & $1.4 \pm 0.8$ & \\
$22: 6(n-3)$ & $21.4 \pm 1.9$ & $2.1 \pm 0.5$ \\
$(n-3) /(n-6)$ & $1.4 \pm 0.1$ & $0.07 \pm 0.02$ \\
\hline
\end{tabular}

$a$ : means of 3 determinations \pm SEM ; $b$ : means of 4 determinations \pm SEM.

The fatty acid composition of the fry (table 6) shows, among the main changes occurring in the fatty acid composition of polar lipids throughout egg development, a tendency for 22:6 (n-3) and 22:5 (n-6) to be preferentially retained in fry originating from the trout fed diets $C$ and $D$, respectively. Similar conclusions concerning 22:6 (n-3) and 16:0 in developing eggs and fry were formulated by Hayes et al. (1973), Ando (1968) and Atchison (1975). 22:3 (n-3) seemed to have a special role in normal fish during development and 22:5 (n-6) in (n-3)-deficient animals. It should be noted that the sum of 20:4 (n-6), 22:5 (n-6) and 22:6 (n-3) was similar (about $40 \%$ ) in fry from trout fed either the deficient or the non-deficient diet. 
TABLE 6

Simplified fatty acid compositions (mole \%) of the polar and neutral lipids of fry originating from mature trout fed diet $C$ or $D$. Results of one extraction of 20 fish for each diet.

\begin{tabular}{lcccc}
\hline \multirow{2}{*}{ Fatty acids } & \multicolumn{2}{c}{ Polar lipids } & \multicolumn{2}{c}{ Neutral lipids } \\
\cline { 2 - 5 } & Diet C & Diet D & Diet C & Diet D \\
\hline$\Sigma$ Sat. & 36.9 & 34.4 & 26.7 & 22.3 \\
$\Sigma(n-7)$ & 3.2 & 0.8 & 11.9 & 3.0 \\
$\Sigma(n-9)$ & 14.9 & 12.1 & 37.9 & 22.2 \\
$\Sigma(n-6)$ & 12.2 & 46.0 & 14.0 & 51.7 \\
$\Sigma(n-3)$ & 32.7 & 6.6 & 9.4 & 0.8 \\
$18: 2(n-6)$ & 1.8 & 5.4 & 7.5 & 25.9 \\
$20: 4(n-6)$ & 8.2 & 21.7 & 3.3 & 10.0 \\
$22: 5(n-6)$ & 1.2 & 14.2 & 0.7 & 3.6 \\
$20: 5(n-3)$ & 2.11 & - & 0.77 & - \\
$22: 6(n-3)$ & 29.0 & 5.6 & 7.9 & 0.8 \\
$(n-3) /(n-6)$ & 1.2 & 0.3 & 2.7 & 0.4 \\
\hline
\end{tabular}

Effects of essential fatty acid deficiency on incubation progress and on embryonic development.

Results concerning the incubation of seven lots of eggs are summarized in table 7. The values fluctuated whatever the origin of the eggs, but eggs originating from fish fed diet $D$ tended to show decreased hatchability.

TABLE 7

Effect of dietary (n-3) fatty acid deficiency on the spawing of rainbow trout.

\begin{tabular}{|c|c|c|c|c|c|c|c|}
\hline \multirow[b]{2}{*}{ Fish $\mathrm{N}^{\circ}$} & \multicolumn{3}{|c|}{$\begin{array}{l}\text { Control trout } \\
\text { Diet C }\end{array}$} & \multicolumn{4}{|c|}{$\begin{array}{l}\text { (n-3) deficient trout } \\
\text { Diet D }\end{array}$} \\
\hline & 1 & 2 & 3 & 4 & 5 & 6 & 7 \\
\hline $\begin{array}{l}\text { Fertilized eggs } \\
\text { Hatching time (days) } \\
\text { Total hatch } \\
\% \text { hatch } \\
\text { Vitellus resorptiona } \\
\text { time (days) }\end{array}$ & $\begin{array}{r}1674 \\
27 \\
908 \\
54\end{array}$ & $\begin{array}{r}1967 \\
28 \\
1738 \\
88\end{array}$ & $\begin{array}{r}1848 \\
27 \\
1760 \\
95\end{array}$ & $\begin{array}{r}1190 \\
27 \\
758 \\
64\end{array}$ & $\begin{array}{r}1343 \\
- \\
0 \\
0\end{array}$ & $\begin{array}{r}1484 \\
30 \\
75 \\
5\end{array}$ & $\begin{array}{r}1409 \\
28 \\
147 \\
11\end{array}$ \\
\hline Mortality $(\%)$ & 46 & 12 & 5 & 36 & 100 & 95 & 89 \\
\hline
\end{tabular}

a : estimated on pools of control and deficient alevins.

The progress of incubation in a typical control fish is presented in figure 1 and in four ( $n-3)$ fatty acid-deficient fish in figure 2. Fertilization efficiency was equivalent and mortality rate was negligible during the first two days that deficient and non-deficient eggs were developing. However, mortality was first observed in the deficient eggs 6 days after fertilization. Each lot was affected differently by (n-3) fatty acid deficiency. In lot 5, which was the least resistant, mortality rate was $96 \%$ at day 11 and reached $100 \%$ at day 22 . In lot 4 , which was the least affected, mortality rate was $36 \%$ at hatching time and progressed during the following weeks. Subsequent fry feeding with the (n-3) fatty acid-deficient diet resulted in a high mortality rate ( $29 \%$ survival 109 days after first food intake), 


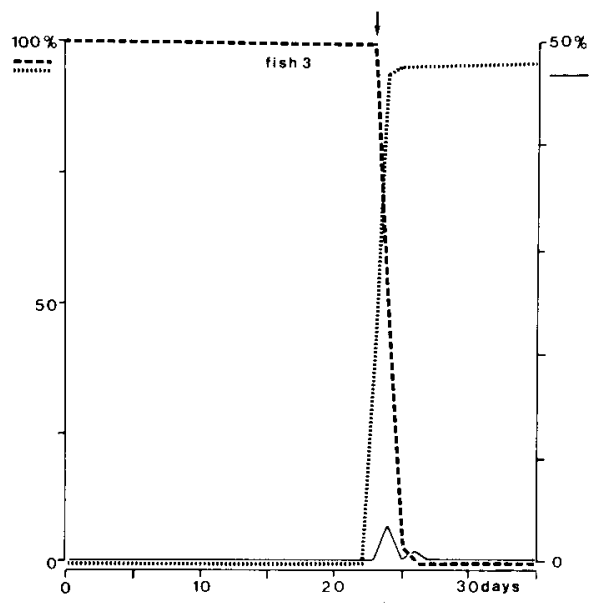

FIG. 1. - Time-course of the hatching of trout-3 eggs. Example of control trout fed diet C. daily mortality rate $(0-50 \%): 0$; $(100-0)$ beginning of eggs $(0-100 \%)$;

For details see table 7.
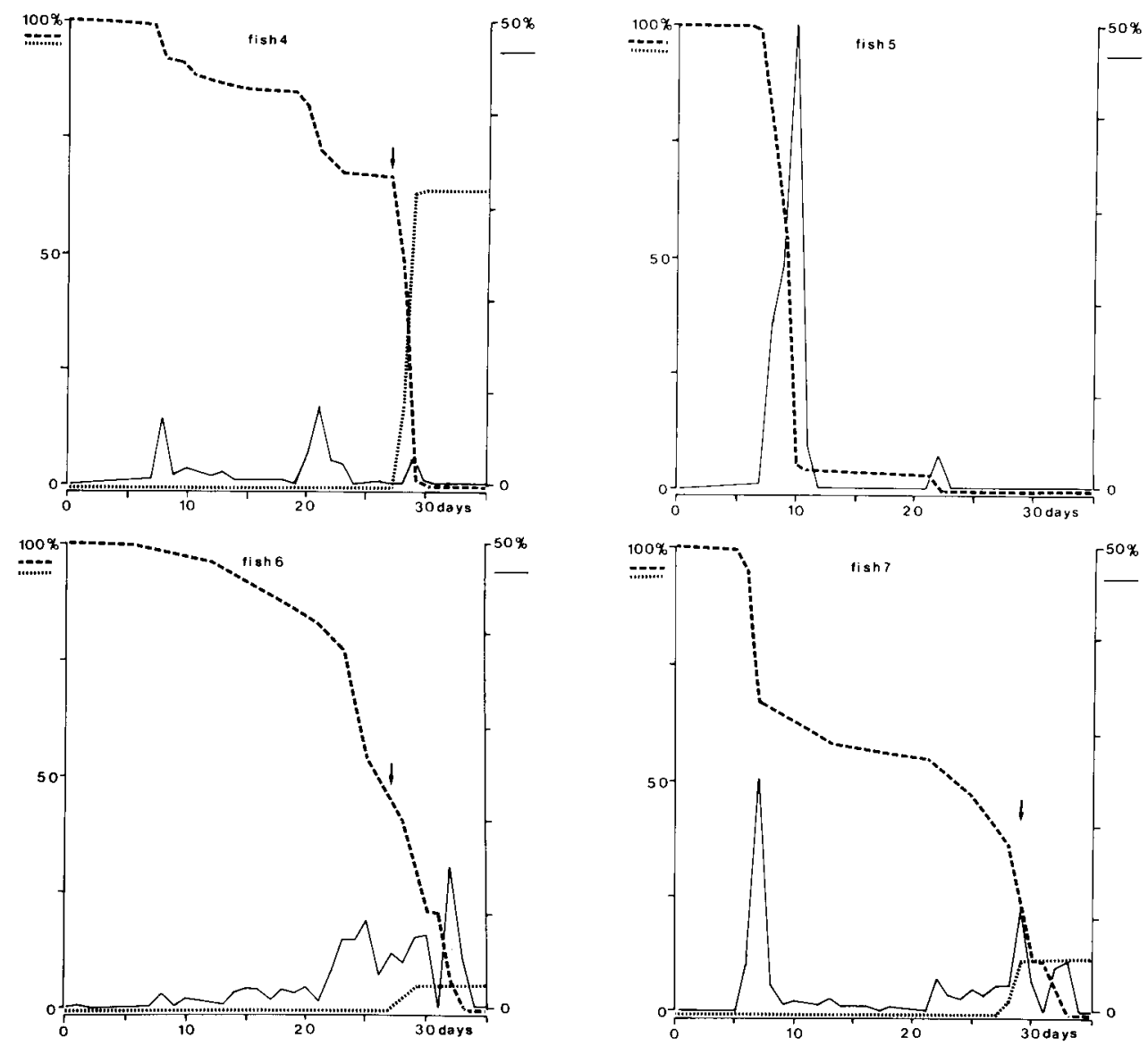

FIG. 2. - Time-course of egg hatching of ( $n$-3) fatty acid-deficient trout 4 to 7 fed diet $D$. For legends see fig. 1 and for details see table 7. 
whereas no control fry died during the same period. In lots 6 and 7, which showed intermediate resistance, the mortality rate increased considerably from day 21-22 after fertilization and fry survival was very low after hatching.

Extensive anomalies were observed at the end of development (fig. 3). Numerous fish larvae showed various kinds of body deformation (curled and helicoidal shapes) and lived until vitellus resorption. Similar effects, recorded by Watanabe (1982) in trout, were prevented by a supplement of $(n-3)$ fatty acids in the broodstock diet. $(n-3)$ fatty acid deficiency can prolong egg development, increasing the time up to hatching by 5 days, whereas the vitellus is resorbed much earlier than in control eggs (table 7). Among the three mortality waves constantly observed during development of the (n-3) fatty acid-deficient eggs,

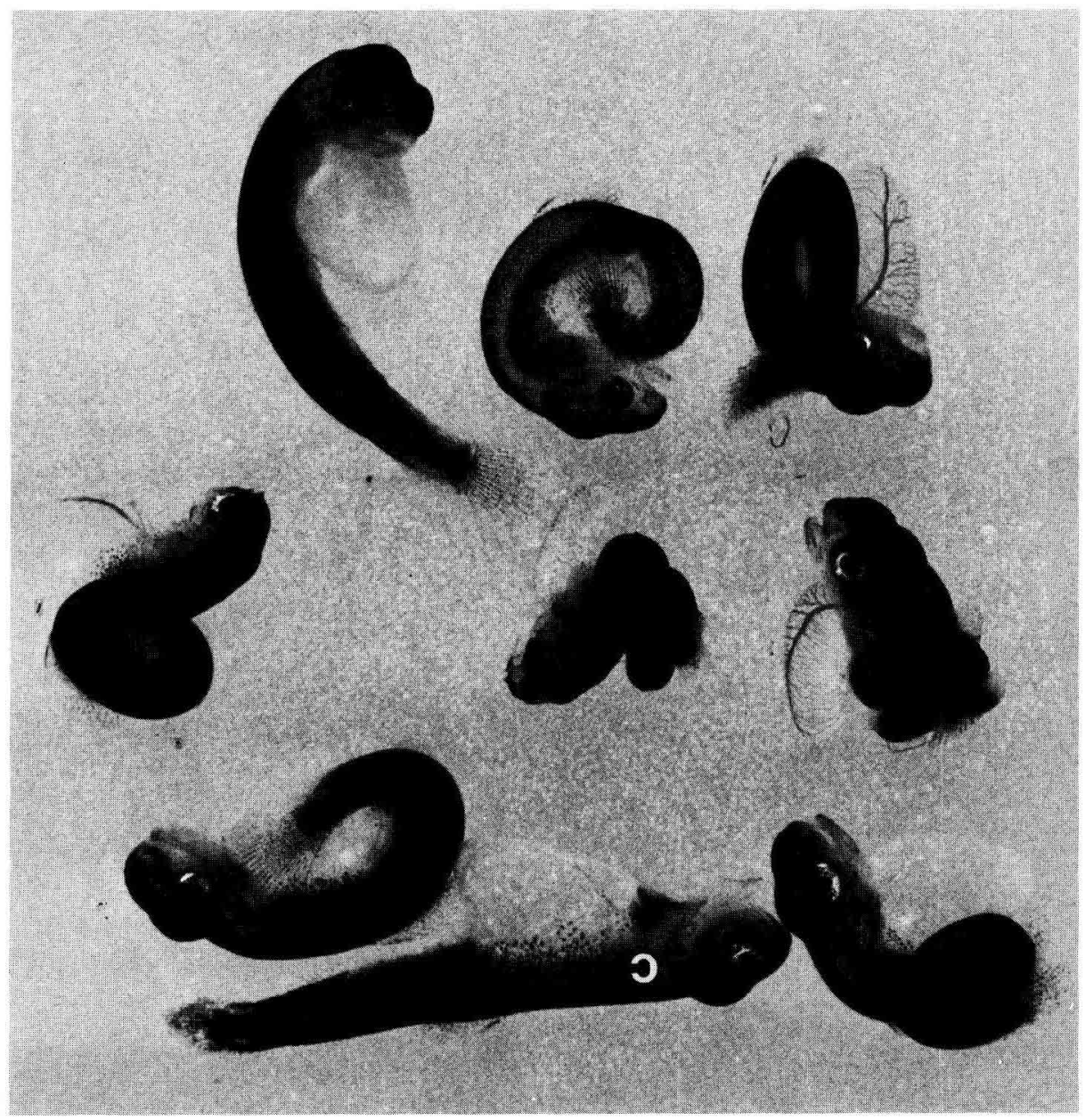

FIG. 3. - Anomalies observed in trout fry hatched from (n-3) fatty acid-deficient eggs. $C$ : control fish at the same developmental stage. 
only the last one at around day 29 could be related to egg hatching, a known process since it also occurred in the control groups. The other two waves at around day 8 and day 22 could not be related to definite developmental events since the mortality test used was obviously a delayed process. In contrast, the morphological observation of fixed embryos revealed that developmental alterations occurred during the first day after fertilization since segmentation disorders were observed at the 16 to 32 -cell stage. In lot 5 eggs, these alterations (fig. 4, A5) led to abnormal morulae (fig. 4, B5) and to further interruption at the blastula stage (fig. 4, C5). In lot 4 eggs, similar alterations were seen (fig. 4, B4) which led to a disarrangement detected at the epiboly stage (fig. 4, D4). Thus, (n-3) fatty acid deficiency could induce early disorders in cellular association.

Disorders observed later (blocking effect before gastrulation or anarchical organogenesis) strengthen the notion that (n-3) fatty acid deficiency acts on the processes of cellular mobility and recognition. It can be concluded that this nutritional deficiency in female trout greatly affects embryonic and larval development, as previously shown in trout (Watanabe, 1982 ; Watanabe et al., 1984c) and red sea bream (Watanabe et al., 1984a,b). However, the incidence of high amounts $(5.4 \%)$ of linoleic acid in the (n-3)-deficient diet on early developmental stages cannot be excluded as it has already been reported by $\mathrm{Yu}$ and Sinnhuber (1976) that the growth of $0.6 \mathrm{~g}$ trout was depressed by high dietary levels $(2.5$ or $5 \%)$ of this fatty acid.

The (n-3) series, especially 22:6 (n-3), probably plays a crucial and specific role in trout reproductive and developmental processes. The functions of the $(n-3)$ series may be related to membrane fluidity and permeability, membrane-bound enzyme activities or the synthesis of oxygenated cyclic and non-cyclic derivatives (Tinoco, 1982). Precursors of oxygenated hormone-like compounds belong to the $(n-6)$ or $(n-3)$ series. Recent works show that prostaglandin-related compounds are formed from 20:5 (n-3) (Fisher and Weber, 1984 ; Tinoco, 1982) and that 20:5 (n-3) and 22:6 (n-3) could be the precursors of hydroxy fatty acids (Boukhchache and Lagarde, 1982 ; Aveldano and Sprecher, 1983). These compounds might act as modulators or mediators in various physiological events, especially in the processes of cellular recognition occurring during embryonic development.

The absence of changes in the quality of the eggs produced by trout fed ethyl linoleate for three months before spawning (Watanabe et al., 1984c) is likely related to the high level of $(\mathrm{n}-3)$ fatty acids remaining in the egg polar lipids (19 vs $34.5 \%$ in control fish). Similar changes in egg composition were observed by Léger et al. (1981b) after feeding adult trout a (n-3) fatty acid-deficient diet three months before the spawning period. It can be concluded that only a long period of (n-3) fatty acid deficiency, one year before spawning in this study, 6 months according to Watanabe (1982), is able to deeply alter egg lipids and affect embryonic development. In contrast, it is not clear why a negative effect on egg incubation was reported in trout, although no changes were observed in the liver and egg polar lipid composition (Watanabe et al., 1984c). Furthermore, our results show that early (n-3) fatty acid deficiency caused a high larval mortality, as reported by Lee et al. (1967) and Yu and Sinnhuber (1975) but in contrast with 

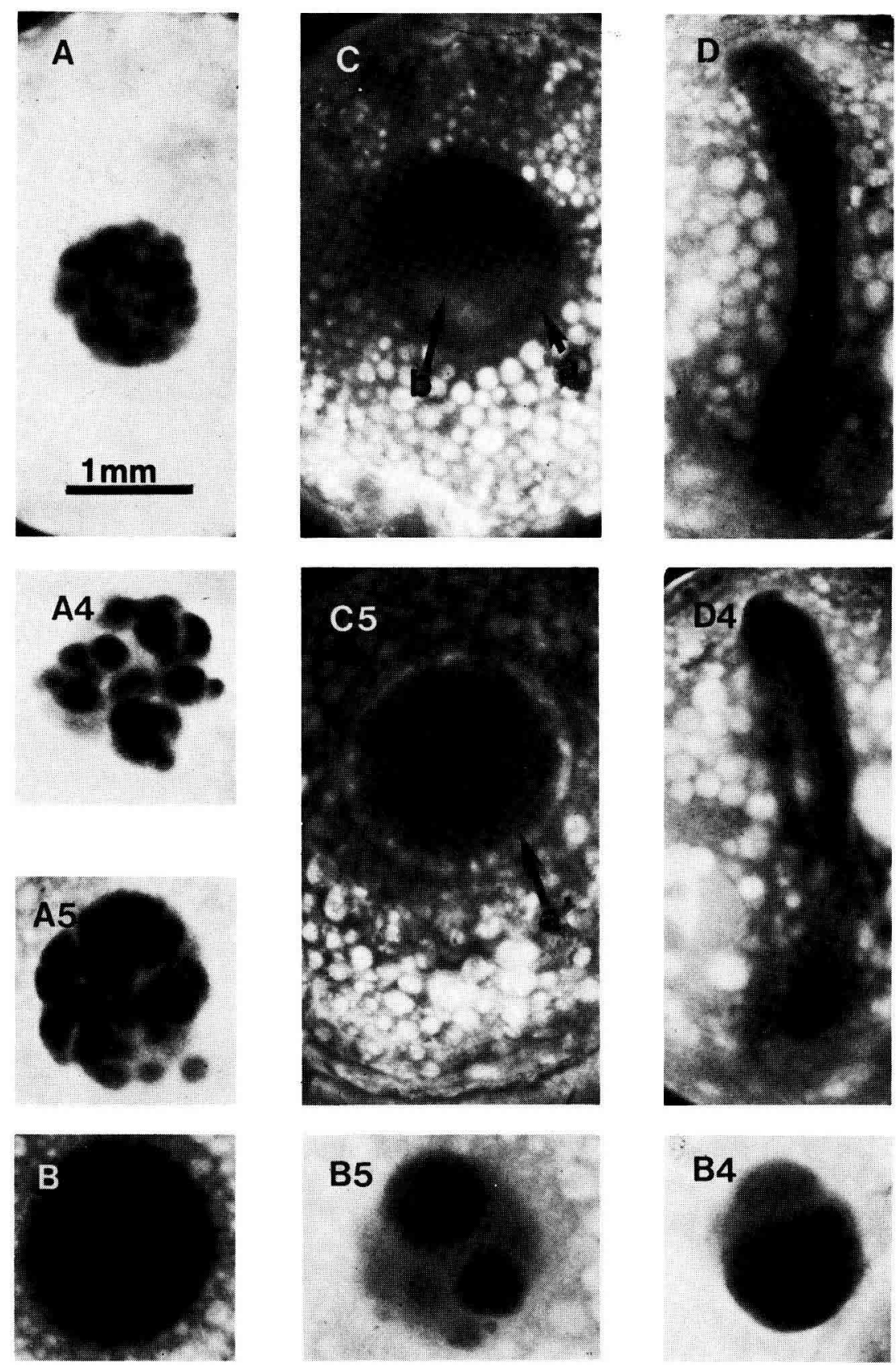

FIG. 4. - Early developmental disorders in the embryos of two female trout fed a (n-3)-deficient diet for one year before spawning.

A, B, C, D : normal development of embryos of control females.

A4, A5 ; B4, B5 ; C5 ; D4 : typical developmental stages of (n-3)-deficient embryos of females 4 and 5 (see table 7 and figure 2).

A, A4, A5 : 1-day embryos (16-32 cells) ; A4, A5 : unequal blastomere cleavage ; B, B4, B5 : 2 day embryos (late morula); B4, B5: irregular groups of blastomeres; C, C5 : 4-day embryos (blastula) ; C5 : embryo blocked at blastula stage in $95 \%$ of the observed eggs of female 5 .

a : periblastic syncitial ring, b : lunule-like blastocoele; $a^{\prime}$ : periblastic syncitial ring separated from the blastodisc. D, D4 : 8-day embryos (5/6 epiboly stage) ; D4 : embryo blocked at epiboly stage in $20 \%$ of the observed eggs of female 4 . 
the results reported by $\mathrm{Yu}$ and Sinnhuber (1976) with half-gram fry and by Castell et al. (1972c) with 11-gram fish. Such discrepancies emphasize the need for additional experimentation in this field.

Reçu en octobre 1984.

Accepté en février 1985.

Résumé. Effets d'une carence en acides gras essentiels (n-3) sur la reproduction de la truite arc-en-ciel.

Nous avons analysé les conséquences d'une alimentation contrôlée en lipides de truites arc-en-ciel adultes sur la composition en acides gras des œufs et des alevins, sur leur taux de survie et d'éclosion.

La composition en acides gras du foie des géniteurs, nourris soit par un aliment du commerce (référence), soit par un aliment déficient en acides gras (n-3), des œufs de ces géniteurs et des alevins a été déterminée.

La différence la plus importante, induite par les lipides alimentaires, se situe au niveau de la carence en 22:6 (n-3) et de la richesse en 20:4 (n-6) et 22:5 (n-6) des phospholipides provenant d'animaux recevant un aliment déficient en acides gras ( $n-3)$ mais riche en 18:2 (n-6).

Tandis que le taux de fertilisation est identique pour les deux lots expérimentaux, deux périodes critiques de forte mortalité, à 8 jours et 22 jours d'incubation, sont observées pour les œufs provenant d'animaux carencés. De plus, le vitellus est résorbé plus rapidement chez les œufs déficients en acides gras $(n-3)$ que chez les œufs témoins, respectivement à 50 jours et 65 jours après la fécondation. Les taux d'éclosion varient de $95 \%$ chez les témoins jusqu'à $5 \%$ chez les carencés. D'importantes malformations sont observées chez les alevins issus de géniteurs carencés.

Nous pouvons en conclure que les acides gras $(n-3)$ et particulièrement les acides gras 22:6 (n-3) jouent un rôle prépondérant dans le développement embryonnaire de la truite.

\section{References}

ANDO K., 1968. Biochemical studies on the lipids of cultured fishes. J. Tokyo Univ. Fish., 54, $61-98$.

ATCHISON G. J., 1975. Fatty acid levels in developing brook trout (Salvelinus fontinalis) eggs and fry. J. Fish. Res. Board Can., 32, 2513-2515.

AVELDANO M. I., SPRECHER H., 1983. Synthesis of hydroxy fatty acids from $4,7,10,13,16$, 19-[1-14C] docosahexaenoic acid by human platelets. J. biol. Chem., 258, 9339-9343.

BOUKHCHACHE D., LAGARDE M., 1982. Interactions between prostaglandins precursors during their oxygenation by human platelets. Biochim. biophys. Acta, 713, 386-392.

BRENNER R. R., 1971. The desaturation step in the animal biosynthesis of polyunsaturated fatty acids. Lipids, 6, 567-575.

CASTELL J. R., LEE D. J., SINNHUBER R. O. 1972a. Essential fatty acids in the diet of rainbow trout (Salmo gairdneri) : lipid metabolism and fatty acid composition. J. Nutr., 102, 93-99.

CASTELL J. R., SINNHUBER R. O., LEE D. J., WALES J. H., 1972b. Essential fatty acids (EFA) in the diet of rainbow trout: Physiological symptoms of EFA deficiency. J. Nutr., 102. 87-92.

CASTELL J. R., SINNHUBER R. O., WALES J. H., LEE D. J., 1972c. Essential fatty acids in the diet of rainbow trout (Salmo gairdneri): growth, feed conversion and some gross deficiency symptoms. J. Nutr., 102, 77-86. 
DI COSTANZO G., FLORENTZ A., LeRAY C., NONNOTTE L., 1983. Structural and functional organization of the brush border membrane in the rainbow trout intestine. Molec. Physiol., 4, 111-123.

FISHER S., WEBER P. C., 1984. Prostaglandin $I_{3}$ is formed in vivo in man after dietary eicosapentaenoic acid. Nature, 307, 165-168.

FLANZY J., BOUDON M., LÉGER C., PIHET J., 1976. Application of Carbowax $20 \mathrm{M}$ as an open-tubular liquid phase in analyses of nutritionaly important fats and oils. J. Chromatogr. Sci., 14, 17-24.

FOLCH J., LEES M., SLOANE-STANLEY G. H., 1957. A simple method for the isolation and purification of total lipids from animal tissues. J. biol., Chem., 226, 497-509.

FRÉMONT L., LÉGER C., PETRIDOU B., GOZZELINO M.-T., 1984. Effects of (n-3) polyunsaturated fatty acid-deficient diet on profiles of serum vitellogenin and lipoprotein in vitellogenic trout (Salmo gairdnerii). Lipids, 19, 522-528.

HAYES L. W., TINSLEY I. J., LOWRY R. R., 1973. Utilization of fatty acids by the developing steel head sac-fry, Salmo gairdneri. Comp. Biochem. Physiol., 45B, 695-707.

HOLMAN R. T., 1970. Biological activities of and requirement for polyunsaturated acids. Progr. chem. Fats Lipids, 9, 607-682.

LEE D. J., ROEHM J. N., YU T. C., SINNHUBER R. O., 1967. Effect of $\omega 3$ fatty acids on the growth rate of rainbow trout, Salmo gairdnerii. J. Nutr., 92, 93-98.

LÉGER C., FRÉMONT L., 1980. Métabolisme des acides gras et des lipides neutres, 215-246. In M. FONTAINE, Nutrition des Poissons, C.N.R.S., Paris.

LÉGER C., FRÉMONT L., BOUDON M., 1981a. Fatty acid composition of lipids in the trout. I. Influence of dietary fatty acids on the triglyceride fatty acid desaturation in serum, adipose tissue, liver, white aitd red muscle. Comp. Biochem. Physiol., 69B, 99-105.

LÉGER C., FRÉMONT L., MARION D., NASSOUR I., DESFARGES M. F., 1981b. Essential fatty acids in trout serum lipoproteins, vitellogenin and egg lipids. Lipids, 16, 593-600.

SHIMMA Y., SUZUKI R., YAMAGUCHI M., AKIYAMA T., 1977. On the lipids of adult carps raised on fish meal and SCP feeds, and hatchabilities of their eggs. Bull. Freshwater Fish. Res., Lab., 27, 35-48.

SINNHUBER R. O., CASTELL J. D., LEE D. J., 1972. Essential fatty acid requirement of the rainbow trout, Salmo gairdneri. Fed. Proc., 31, 1436-1441.

TAKEUCHI T., WATANABE T., 1976. Nutritive value of $\omega 3$ highly unsaturated fatty acids in pollock liver oil for rainbow trout. Bull. jap. Soc. Sci. Fish., 42, 907-919.

TAKEUCHI T., WATANABE T., 1977. Effect of eicosapentaenoic acid and docosahexaenoic acid in pollock liver oil on growth and fatty acid composition of rainbow trout. Bull. jap. Soc. Sci. Fish., 43, 947-953.

TAKEUCHI T., WATANABE T., 1982. Effects of various polyunsaturated fatty acids on growth and fatty acid compositions of rainbow trout Salmo gairdneri, Coho salmon, Onchorhynchus kisutch, and Chum salmon Onchorhynchus keta. Bull. jap., Soc. Sci. Fish., 48, 1745-1752.

TINOCO J., 1982. Dietary requirements and functions of $\alpha$-linolenic acid in animals. Prog. Lipid Res., 21, 1-45.

TINOCO J., BABCOCK R., HINCENBERGS I., MEDWADOWSKI B., MILJANICH P., 1978. Linolenic acid deficiency : changes in fatty acid patterns in female and male rats raised on a linolenic acid-deficient diet for two generations. Lipids, 13, 6-17.

Watanabe T., 1982. Lipid nutrition in fish. Comp. Biochem. Physiol., 73B, 3-15.

WATANABE T., ARAKAWA T., KITAJIMA C., FUJITA S., 1984a. Effect of nutritional quality of broodstock diets on reproduction of red sea bream. Bull. jap. Soc. Sci. Fish., 50, 495-501.

WATANABE T., OGINO C., KOSHIISHI Y., MATSUNAGA T., 1974a. Requirement of rainbow trout for essential fatty acids. Bull. jap. Soc. Sci. Fish., 40, 493-497.

WATANABE T., OHHASHI S., ITOH A., KITAJIMA C., FUJITA S., 1984b. Effect of nutritional composition of diets on chemical components of red sea bream broodstock and eggs produced. Bull. jap. Soc. Sci. Fish., 50, 503-515.

WATANABE T., TAKASHIMA F., OGINO C., 1974b. Effect of dietary methyl linolenate on growth of rainbow trout. Bull. jap. Soc. Sci. Fish., 40, 181-188.

WATANABE T., TAKEUCHI T., 1976. Evaluation of pollock liver oil as a supplement to diets for rainbow trout. Bull. jap. Soc. Sci. Fish., 42, 893-906. 
WATANABE T., TAKEUCHI T., SAITO M., NISHIMURA K., 1984c. Effect of low protein-high calory or essential fatty acid deficient diet on reproduction of rainbow trout. Bull. jap. Soc. Sci. Fish., 50, 1207-1215.

WATANABE T., TAKEUCHI T., SHIMMA Y., 1978. Influence of SCP feed on lipid contents and fatty acid composition of rainbow trout. Bull. Freshwater Fish. Res. Lab., 28, 37-46.

WIEGAND M. D., IDLER D. R., 1982. Synthesis of lipids by the rainbow trout (Salmo gairdneri) ovary in vitro. Can. J. Zool., 60, 2683-2693.

YU T. C., SINNHUBER R. O., 1972. Effect of dietary linolenic acid and docosahexaenoic acid on growth and fatty acid composition of rainbow trout (Salmo gairdneri). Lipids, 7. 450-454.

YU T. C., SINNHUBER R. O., 1975. Effect of dietary linolenic and linoleic acids upon growth and lipid metabolism of rainbow trout (Salmo gairdneri). Lipids, 10, 63-66.

YU T. C., SINNHUBER R. O., 1976. Growth response of rainbow trout (Salmo gairdneri) to dietary $\omega 3$ and $\omega 6$ fatty acids. Aquaculture, 8, 309-317.

YU T.C., SINNHUBER R. O., HENDRICKS J. D., 1979. Reproduction and survival of rainbow trout (Salmo gairdneri) fed linolenic acid as the only source of essential fatty acids. Lipids, 14. 572-575. 